Article

\title{
Life Cycle Assessment (LCA) of Different Kinds of Concrete Containing Waste for Sustainable Construction
}

\author{
Francesco Colangelo ${ }^{(D)}$, Antonio Forcina, Ilenia Farina and Antonella Petrillo * (iD \\ Department of Engineering, University of Naples "Parthenope", Isola C4, \\ Centro Direzionale Naples (NA) 80143, Italy; colangelo@uniparthenope.it (F.C.); \\ antonio.forcina@uniparthenope.it (A.F.); ilenia.farina@uniparthenope.it (I.F.) \\ * Correspondence: antonella.petrillo@uniparthenope.it; Tel.: +39 081-547-6747
}

Received: 19 February 2018; Accepted: 2 May 2018; Published: 11 May 2018

\begin{abstract}
Concrete production causes significant environmental damage during its entire life cycle due to the large consumption of natural aggregate. The aim of this research was to use the Life Cycle Assessment (LCA) methodology to conduct a comparative analysis of four different concrete mixtures, i.e., construction and demolition waste (CDW), incinerator ashes, marble sludge, and blast furnace slag. The LCA study was implemented in the Campania Region of Italy. The main contribution of the study was that it proposed the use of "green" recycled aggregates in concrete production in order to assess the reduction of potential adverse impacts, from both environmental and energy perspectives. $\mathrm{SimaPro}^{\odot}$ software was used to conduct the analysis. The main results of the research showed that the recycled aggregates that were analyzed were preferable to traditional concrete. In particular, the recycled aggregate that had the least adverse impact on the environment was blast furnace waste.
\end{abstract}

Keywords: LCA; C\&D waste; MSWI; marble sludge; recycled aggregate concrete; blast furnace slags

\section{Introduction}

Concrete is a key component in constructing buildings because it is the most commonly used material in infrastructures [1]. It also is known that the construction industry is one of the main consumers of raw materials [2]. As discussed by several authors and in detail by [3] the main component of concrete is cement, which releases significant quantities of carbon dioxide $\left(\mathrm{CO}_{2}\right)$ into the atmosphere [4]. In other words, the production of concrete has a notable impact on the environment, and environmental problems are known to be quite serious in the construction industry [5-8]).

The scientific community devotes significant attention on finding sustainable solutions to avoid the use of ordinary concrete and to manage its environmental impacts [9]. In order to achieve this purpose, it is possible to replace (totally or partially) natural aggregates with recycled aggregates (e.g., fly ash (FA), blast furnace slag, and murble sludge) [10-14]). Also, complete replacement of cement with alkali-activated binders can be another option [15-17]; and still another option could be to replace cement with recycled fibers [18,19].

Another advantage is that the addition of slag enhances the strength of concrete and reduces the heat of hydration [20]. This replacement also allows a reduction in energy consumption and $\mathrm{CO}_{2}$ emissions, since blast furnace slag is a product that has already undergone the transformation from carbonate to oxide with the consequent release of $\mathrm{CO}_{2}$. Blast furnace slags can be used in several applications, including road construction base materials after grinding and cementitious materials [21] since they contain high amounts of calcium silicate, glass, and high-quality ceramic products [22] They also are mechanochemically treated so they can be recycled as a low-cost adsorbent $[23,24]$. Thus, in the 
concrete production industry there is increasing interest in the use of new kind of aggregates due to some of their advantages, such as social acceptance, economic advantage, and sustainability [25]. Their use can reduce the carbon footprint and to help sustain growth without harming the environment [26].

However, it is necessary to evaluate these new materials in terms of their performance, quality, and costs, as well as their social and environmental aspects. To achieve this goal, a well-know tool, Life cycle assessment (LCA), can be used successfully to analyze the environmental performance of the entire life cycle of a product or of a process [27-29]. In fact, LCA allows us to balance the use of material and energy and quantify the overall environmental impacts [30,31]. Definitively, LCA is potentially a promising technique that can be useful in evaluating the environmental performance of construction materials [32-38].

According to the previous consideration, the aim of this research was to develop an environmental analysis of four specific mixtures of concretes with recycled aggregates. The paper is organized as follows. Section 2 presents an overview of the literature on LCA and concrete made from recycled aggregates. Materials and methods are defined in Section 3. A real case study is presented in Section 4, and our conclusions are summarized in Section 5.

\section{State of Art of LCA and Recycled Aggregates Concrete}

Because of limited natural resources, the environmental assessment of concrete made from recycled aggregates through the LCA approach is a strategic issue and a major challenge [39]. Concrete recycling operations have three main benefits, i.e., (1) they reduce the demand for new resources; (2) they reduce energy production costs; and (3) they recycle waste that would otherwise be landfilled [40]. The recycling of concrete is an important environmental challenge, and there are many case studies presented in the literature. An investigation on the Scopus data base using as keywords the search string "Life Cycle Assessment AND Concrete" identified 1321 publications since 1983, the first year the document was published, to February 2018 (the investigation period). Papers were selected by applying the following criteria: (1) Article; (2) abstract; and (3) key words. The scientific research that is available indicates that there is increasing interest in this topic. The year 2017 had more documents published on this topic (182 publications) than any other year from 1983 through 2016. Regarding where the documents were published, it was not surprising that most of them (263) were published in the United States.

Then, the analysis was refined by applying a search string as follows "Life Cycle Assessment AND Recycled Concrete". In this case, the number of publications identified in the survey decreased significantly to a total of 87 from 2003, the first year a related document was published, to February 2018 , the investigation period. Thus, it is evident that the LCA of "recycled concrete" is still a limited research area despite the increasing interest in the topic in recent years.

According to the previous analysis, it is important to point out that some recent studies aimed at evaluating the environmental interest of using recycled aggregates, in comparison with natural aggregates, as analyzed by [41] For this purpose, a recent interesting study was conducted by [42]. In their study, 216 concrete mixes from 24 references (selected from papers published in reference journals and conference proceedings) were analyzed in order to define the best concrete solutions from environmental and economic perspectives. The results showed that cement is the main component that causes adverse environmental impacts, so the use of superplasticizer has been advised to indirectly decrease the amount of cement required. It also was apparent that reducing adverse environmental impacts are not necessarily associated with higher costs.

Concerning the environmental impacts, an interesting study was proposed by [43] in which the environmental impacts of using coarse natural aggregate (NA) and coarse recycled concrete aggregate (RCA) were analyzed in the New York City area. The study showed that the replacement of NA with RCA, as a concrete aggregate, had no significant effect on the environmental impact of concrete production. Even so, the research pointed out that avoiding the landfilling of construction and 
demolition waste $(C D W)$ will be a result of producing RCA concrete, provided that $C D W$ is recycled only for the purpose of producing concrete aggregate.

An interesting study was proposed by [44] in which green concrete mixes were compared with a conventional concrete mix. The final results highlighted that RCA with fly ash (FA) was the most suitable mixture. [36] compared the environmental impacts of a recycled concrete and an ordinary concrete. In the analysis, they pointed out that recycled concrete had less impact in terms of greenhouse gas emissions. Some interesting studies have proposed the use of alternative concretes by replacing the virgin raw materials [38,45-47].

The bibliographic analysis showed that a lot of the recent research has been dedicated to the investigation of the use of recycled aggregates to replace ordinary cement. Thus, all of the existing studies have highlighted the importance of developing environmental impact analyses that address the local and national situations. Different from the documents we analyzed concerning previous research, the aim of our research was to help address the paucity of such analyses that specifically deal with the situation in Italy, where scientific literature on this subject is scarce.

\section{Materials}

\subsection{Construction and Demolition Waste (CDW)}

Construction and demolition waste (CDW) accounts for around $25-30 \%$ of the waste produced in Europe, and these wastes are voluminous and heavy [48]. Such waste includes numerous materials, such as bricks, gypsum, concrete, glass, metals, wood, plastics, solvents, and asbestos [49]. The CDW derives mainly from the construction of civil buildings and infrastructures, from the total or partial demolition of buildings and civil infrastructures, and from planning and road maintenance [50]. In order to be reused, it must be treated in special crushing and selection plants, which must meet the technical requirements established in the Waste Framework Directive (2008/98/EC). The Directive provides a framework to guide the European society to recycling with the aim of achieving at least $70 \%$ (by weight) of non-hazardous construction and demolition waste by 2020. As demostrated by [51], the technology for the separation and recovery of CDW is well established and competitive in terms of the costs to be incurred.

\subsection{Incineration Ashes}

Incinerator ashes are obtained from the incineration of municipal solid waste (MSW), so their composition is related strictly to the composition of the raw MSW, the combustion conditions, and the operational conditions of the plant. Chemical substances emitted by an incinerator include organic compounds that contain chlorine, polycyclic aromatic hydrocarbons (IPA), volatile organic compounds (VOCs), trace elements (lead, cadmium, and mercury), hydrochloric acid, nitrogen oxides, sulfur oxides, and carbon oxides. Many of these compounds dissipate in the atmosphere together with dust, bottom ash, and fly ash.

The composition of the latter depends on the lifestyle and waste recycling process of a country, and, for this reason, it varies from country to country [52]. The most common chemical compounds and elements found in the fly ash from Municipal Solid Waste Incineration (MSWI) are oxides and large amounts of heavy metals, including $\mathrm{Cr}, \mathrm{Cu}, \mathrm{Hg}, \mathrm{Ni}, \mathrm{Cd}, \mathrm{Zn}$, and $\mathrm{Pb}$. Such metals may be harmful to the environment and may cause leaching problems, and for this reason they must be treated appropriately [53].

After the treatment, the slags can be reused, rather than disposed of as waste because of their environmental compatibility. The most common reuses of fly ash are roadside substrates, ceramic material, concretes and mortars, infrastructure, and landfill covers. 


\subsection{Marble Sludge}

Marble is a metamorphic rock that consists primarily of calcite $\left(\mathrm{CaCO}_{3}\right)$ and dolomite $\left(\mathrm{CaMg}\left(\mathrm{CO}_{3}\right)_{2}\right)$. During the processing of marble, $30 \%$ of the stone goes to scrap, and the amount of scrap marble is expected to increase since production is increasing in the marble industry [53]. Calcium carbonate is used in several sectors, such as the deacidification of agricultural land; the production of cements; the production of paper, paints, and polypropylene; the production of sodium carbonate; as a neutralizer for acidic industrial wastewater; for the absorption of heavy metals; in production of lime; and in the cosmetic and pharmaceutical industries. The amount of waste generated is a big issue for the companies since the waste must be disposed in landfills. This approach is in contrast with the goals of sustainable development, which are focused on zero waste production through the full reuse of secondary raw materials by means of recovery and recycling procedures. There are two important aspects associated with this approach, i.e., economic and environmental aspects, because the companies would have lower expenses related to landfilling and higher revenues due to the sale of micronized calcium carbonate. In fact, using scrap materials that come from recovery and recycling operations means that they are no longer considered to be wastes; rather, they are now considered to be raw materials and secondary materials to be used in additional production processes. This is useful to pursue the dual objective of minimizing the generation of waste to be disposed and of reducing the burden for the company that also obtains an added value [54].

\subsection{Blast Furnace Waste}

Blast furnace slag results from the physical separation, based on density differences, that occurs in the blast furnace between the cast iron and all of the other oxides that do not undergo reduction in the metallic state. The composition of the slag depends on the production process, on the characteristics of the materials, and on the technologies that are used. The materials consist mainly of calcium oxide $(\mathrm{CaO})$, magnesium oxide $(\mathrm{MgO})$, silicon dioxide $\left(\mathrm{SiO}_{2}\right)$, some aluminum oxide $\left(\mathrm{Al}_{2} \mathrm{O}_{3}\right)$, and smaller quantities of other mineral compounds. After the slag is extracted from the blast furnace, it is subjected to rapid and intense cooling and to a granulation process. This process guarantees the formation of a glassy phase and a structure that gives hydraulic characteristics to the slag that allow it to be used to replace up to $70 \%$ of the limestone and clay used in the production of Portland cement with several other benefits [55]. In fact, the aim of the concrete industry is to substitute other cementitious materials for Portland cement, especially waste materials from industrial processes.

\section{Methodology and Results}

The ISO 14040 standard systematically defines the LCA methodology by explaining four different phases. The first phase is the goal phase, which defines the context of the study. The second phase is the life cycle inventory (LCI) analysis, which defines the raw materials that are the inputs to the system. The third phase is the impact assessment phase, which identifies the potential environmental effects. The fourth and last phase is the interpretation phase, in which information from the results are evaluated [56,57].

\subsection{Goal and Scope Definition}

The environmental implicatons of using recycled aggregates in Campania, a region located in South Italy, were analyzed in this research. (See Figure 1). 


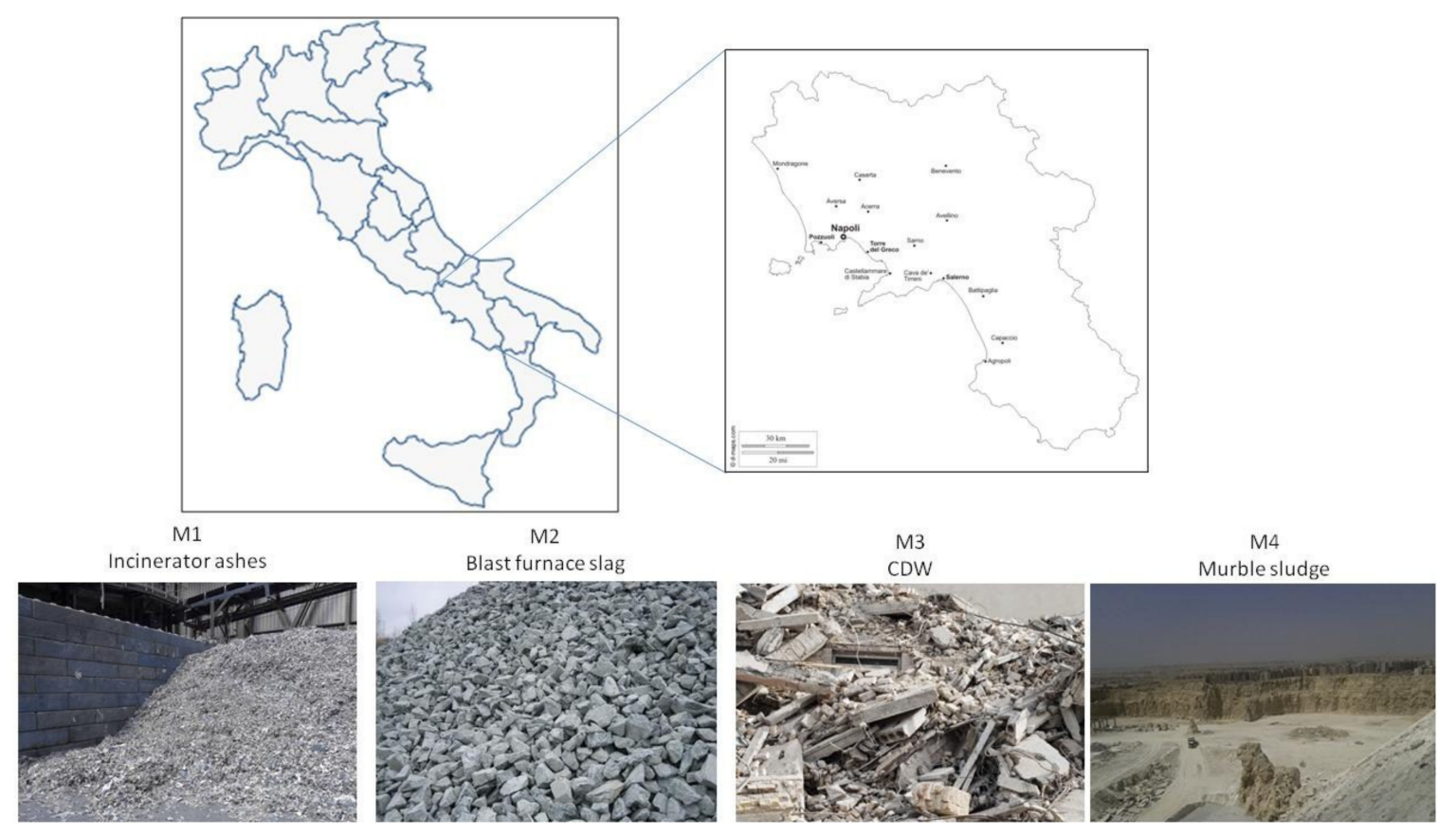

Figure 1. Location of natural aggregate and mixed recycled aggregate production.

In detail, four different concrete mixtures composed of recycled aggregates were analyzed. The mixtures were as follows:

- $\quad$ Mixture 1: concrete with incinerator ashes.

- Mixture 2: concrete with blast furnace slag.

- $\quad$ Mixture 3: concrete with construction and demolition waste.

- $\quad$ Mixture 4: concrete with murble sludge.

Table 1 shows mix design for each of the mixtures.

Table 1. Mix design of concrete.

\begin{tabular}{ccccccc}
\hline Materials & Unit & \multicolumn{4}{c}{ Mixtures } & Natural Concrete \\
\hline- & - & M1 & M2 & M3 & M4 & - \\
Cement (Portland) & {$[\mathrm{kg}]$} & 350 & 350 & 350 & 350 & 350 \\
Water & {$[\mathrm{kg}]$} & 175 & 175 & 175 & 175 & 175 \\
Natural sand & {$[\mathrm{kg}]$} & 937.5 & 937.5 & 937.5 & 937.5 & 937.5 \\
Natural stone & {$[\mathrm{kg}]$} & - & - & - & - & 937.5 \\
Recycled aggregate (MSW) & {$[\mathrm{kg}]$} & 937.5 & - & - & - & - \\
Murble sludge & - & - & - & - & 937.5 & - \\
Recycled aggregate & - & - & 937.5 & - & - & - \\
CDW & - & - & - & 937.5 & - & - \\
- & - & - & - & - & - & - \\
\hline
\end{tabular}

\subsection{Functional Unit}

The functional unit was defined as $1 \mathrm{~m}^{3}$ of concrete (with a specific weight equal to about $2400 \mathrm{~kg} / \mathrm{m}^{3}$ ) to facilitate data management and application. Also it was assumed that the different types of mixtures have approximately the same strength and durability performance, e.g., the same mechanical properties, workability, and durability-related properties. Note that $1 \mathrm{~m}^{3}$ of concrete was chosen as the function unit since, as suggested by [58] $1 \mathrm{~m}^{3}$ of concrete is more representative than $1 \mathrm{~kg}$, and it can be stated that the densities of the three samples are very similar. In this study, it was hypothesized that the cement content and the functional performance of the concrete were constant. 


\subsection{System Boundaries}

In our research, the production phase (excluding the treatment and disposal phases) constitutes boundaries of the system. The motivation for this choice was our awareness that the production phase is the most relevant phase in terms of environmental impacts, as demonstrated by several authors [59-61]. This phase includes the processing of raw materials, transportation, and the production of concrete. Also, the boundaries of the system include the energy required for the processing and transportation of the materials, for the treatment of artificial aggregates (if needed), and also for mixing. In order to properly compare the impacts that result from the different mixtures, the same distances were hypothesized, i.e., (1) $70 \mathrm{~km}$ between the concrete mixing plant and the concrete production plant and (2) $20 \mathrm{~km}$ from the concrete production plant to the retrieval point for the artificial aggregate. Figure 2 shows the boundaries of the system.

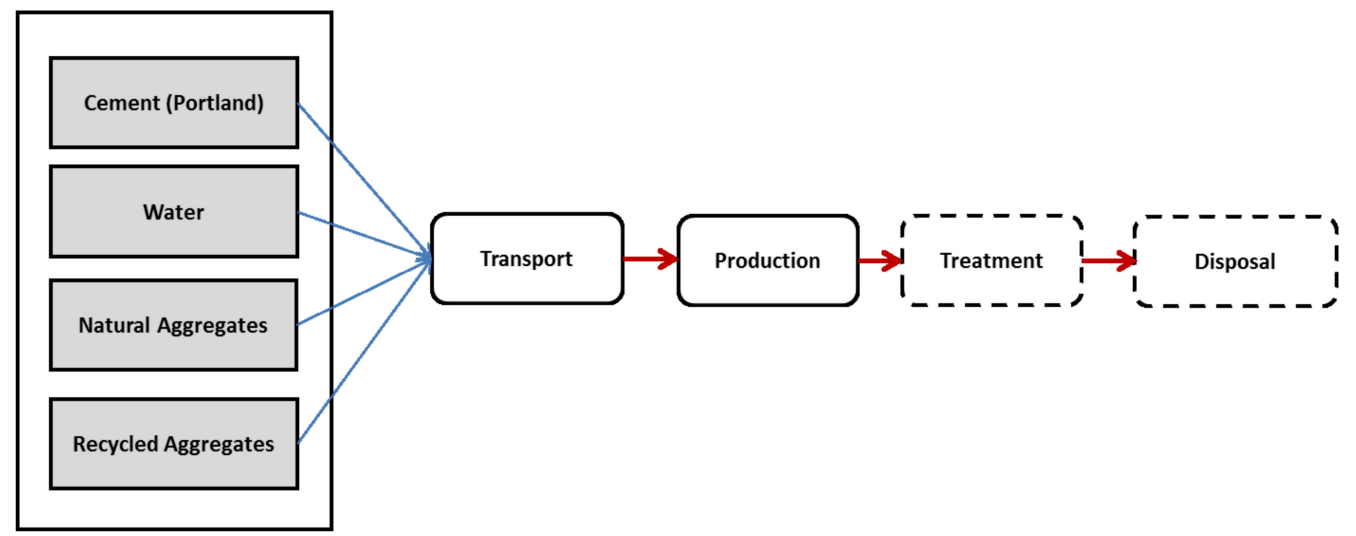

Figure 2. System boundaries.

\subsection{Inventory Analysis}

At this stage of LCA, we considered all of the inputs and outputs of the life cycle phases. Primary data were collected from the Italian Technical Economic Association of Concrete (ATECAP) and during visits to the production and recycle plants. Cement data were obtained from [49]. Ecoinvent v.3 or ELCD (European Life Cycle Databases) were used to complete any missing data. In addition, the literature review was used to integrate the inventory analysis [62]. The LCI data that were considered for each process are shown in Figure 3.

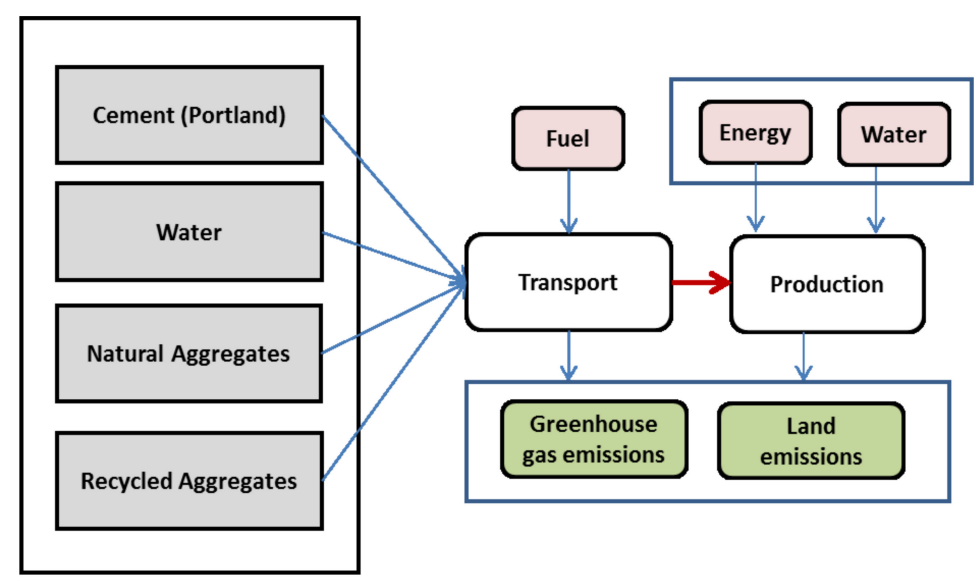

Figure 3. Mixed concrete production process.

Table 2 shows the costs of electricity, fuel, and water associated with the raw material and the natural aggregates. 
Table 2. Inventory data related to the extraction of natural raw material and to the production of NA.

\begin{tabular}{cccc}
\hline LCI & Unit & Raw Material Extraction & Natural Aggregates Production \\
\hline Electric energy consumption & {$[\mathrm{kWh} / \mathrm{t}]$} & - & 1.85 \\
Diesel consumption & {$[1 / \mathrm{t}]$} & 0.40 & 0.50 \\
Water consumption & {$[1 / \mathrm{t}]$} & - & 0.45 \\
\hline
\end{tabular}

\subsection{Impact Assessment}

The impact assessment helped quantify the "magnitude" of the potential impacts through four steps. The first step was called "classification", the aim of which was to define the impact categories for each of the inventory items. The second step was the so-called "characterization step", that aimed to classify each impact into its impact category. The second step was followed by the "normalization step", which sought to define local or global environmental impacts. The last step was "weighting". Its aim was to classify the impact categories. We used Eco-indicator 99 in SimaPro, which is one of the most extensively used impact assessment methods in LCA. It is an end-point approach (or damage approach) that considers 11 impact categories in three damage categories, i.e., (1) human health (expressed as Disability Adjusted Life Years (DALY); (2) depletion of resourses; and (3) quality of the ecosystem [63].

Note that most of the data in this study were assumed to occur within the European context, but some damages were assumed to occur on global scale, such as the depletion of the ozone layer; greenhouse effects; and damages from some radioactive substances. Different damages from some persistent carcinogenic substances also were modelled in the regions adjoining Europe.

The damages estimates were comparable, and they were summed in a single score, i.e., the Eco-indicator expressed in Points (Pt) or MilliPoints (MPt), which represents the overall performance of the system that was investigated in environmental energy terms. In other words, the point $(\mathrm{pt})$ corresponds to $1 / 1000$ of a year lost in the life of a healthy European citizen.

\subsection{Interpretation, Results, and Discussion}

All mixtures were studied in terms of environmental impact using SimaPro 8 software (Pré Consultants, Amersfoot, The Netherlands). Results for the environmental damage (resources, ecosystem quality, and human health) showed that the main environmental damage was related to human health. The results also showed that the transport of ordinary concrete had the greatest impact.

Figure 4 presents a comparison of the impacts of four mixtures of ordinary concrete. The analysis highlighted the fact that ordinary concrete had the greatest impact in all categories. Concrete with a mixture of incinerator ash was slightly better than concrete with aggregate based on murble sludge.

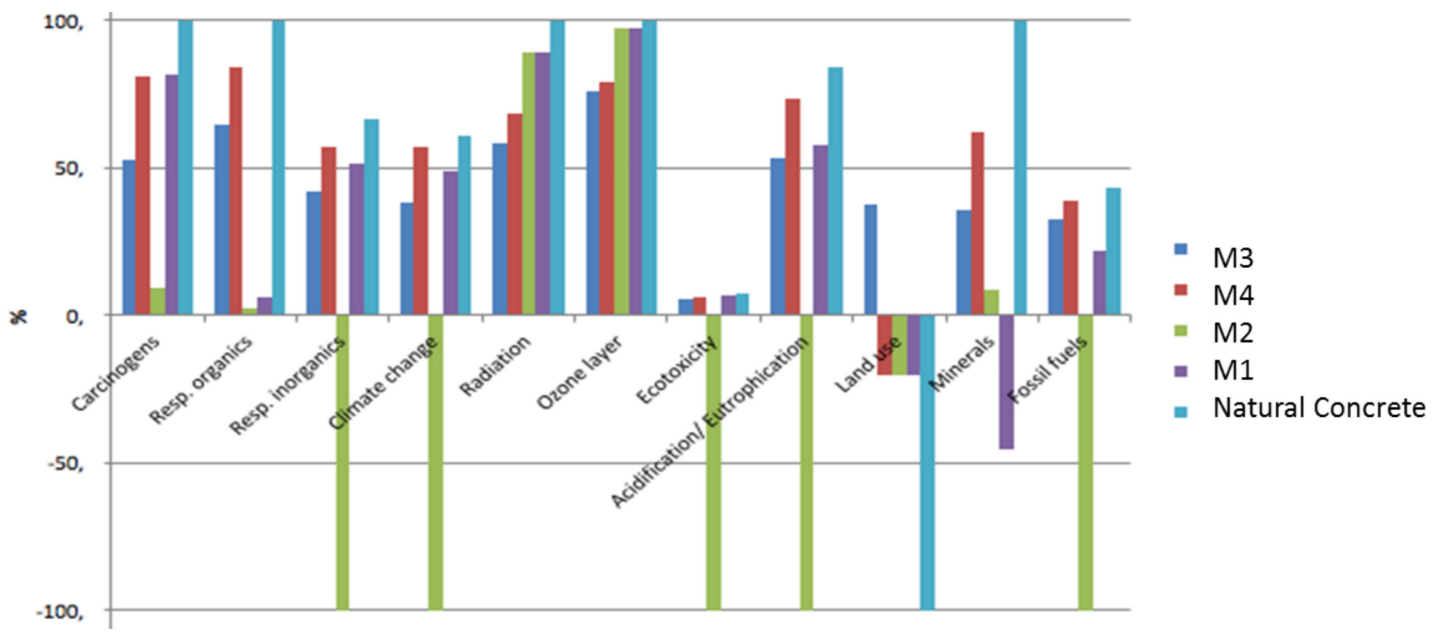

Figure 4. Characterization. 
In addition, note that all of the mixtures that were considered had overall less values in all impact categories and less consumption of resources.

Table 3 summarizes the quantities of the main substances emitted into the air. The yellow color highlights the main critical issues for each mixture. In detail, $\mathrm{CO}_{2}$ emissions are relevant for all mixtures but, above all, for ordinary concrete.

Table 3. Air emissions.

\begin{tabular}{ccccccc}
\hline Substance & Unit & M1 & M2 & M3 & M4 & Ordinay Concrete \\
\hline Aluminium & $(\mathrm{g})$ & 6.152 & 6.152 & 3.784 & 6.52 & 6.558 \\
Ammonia & $(\mathrm{g})$ & 3.672 & 8.611 & 4.780 & 9.114 & 11.569 \\
Butane & $(\mathrm{g})$ & 1.257 & 1.257 & 0.996 & 1.257 & 1.259 \\
Carbon dioxide, bio. & $(\mathrm{kg})$ & 229.826 & 282.972 & 181.693 & 282.972 & 285.755 \\
Carbon dioxide, fossil & $(\mathrm{kg})$ & 24.385 & 24.385 & 16.703 & 24.385 & 24.218 \\
Carbon monoxide, f. & $(\mathrm{g})$ & 214.679 & 214.679 & 146.162 & 214.679 & 239.090 \\
Ethane & $(\mathrm{g})$ & 0.740 & 0.740 & 0.259 & 0.740 & 1.399 \\
Methane, biogenic & $(\mathrm{g})$ & 2.374 & 2.374 & 1.472 & 2.374 & 2.830 \\
Nitrogen oxides & $(\mathrm{g})$ & 447.672 & 447.672 & 288.400 & 447.672 & 479.243 \\
Nitrogen oxides & $(\mathrm{g})$ & 56.867 & 56.867 & 38.4286 & 56.867 & 63.351 \\
Propane & $(\mathrm{g})$ & 1.241 & 1.241 & 0.985 & 1.241 & 1.245 \\
Sulfur dioxide & $(\mathrm{g})$ & 109.074 & 109.074 & 72.756 & 109.074 & 125.078 \\
\hline
\end{tabular}

Table 4 shows land emissions. The main critical issue is related to release of oils into the soil.

Table 4. Land emissions.

\begin{tabular}{ccccccc}
\hline Substance & Unit & M1 & M2 & M3 & M4 & Ordinay Concrete \\
\hline Calcium & $(\mathrm{g})$ & 2.077 & 2.072 & 1.645 & 2.077 & 2.109 \\
Carbon & $(\mathrm{g})$ & 1.611 & 1.611 & 1.278 & 1.611 & 1.631 \\
Chloride & $(\mathrm{g})$ & 1.813 & 1.784 & 1.436 & 1.813 & 1.841 \\
Iron & $(\mathrm{mg})$ & 82.954 & 82.954 & 54.796 & 82.954 & 105.607 \\
Oils, unsp. & $(\mathrm{g})$ & 65.787 & 65.787 & 54.752 & 65.787 & 61.551 \\
Orbencarb & $(\mu \mathrm{g})$ & 67.029 & 67.029 & 50.522 & 67.029 & 77.851 \\
Sodium & $(\mathrm{g})$ & 1.036 & 1.036 & 0.820 & 1.036 & 1.052 \\
Zinc & $(\mathrm{mg})$ & 3.299 & 3.299 & 2.243 & 3.299 & 3.806 \\
Zinc & $(\mathrm{mg})$ & 8.442 & 8.422 & 6.710 & 8.442 & 8.517 \\
\hline
\end{tabular}

\section{Conclusions}

In this study, different kinds of concrete mixtures containing waste were evaluated from an environmental perspective by applying the LCA methodology. The aim of this research was to contribute to the study of the most sustainable concrete compositions, with natural and recycled aggregates, through a life cycle analysis. The main results of the research showed that the analyzed recycled aggregates are preferable in comparision with traditional concrete. In particular, the recycled aggregate that had the least impact was blast furnace waste.

In addition, this research confirmed that (1) the production of OPC (Ordinary Portland Concrete) in Campania, Italy is associated with high $\mathrm{CO}_{2}$ emissions; (2) the use of recycled aggregates ensured the reduction of GW (Global Warming); (3) the use of recycled aggregates can improve the environmental management problem.

In conclusion, the results of the study indicated that the use of recycled aggregates is a potential field of research that could ensure tangible environmental benefits in the future in the context of the Campania Region and in a national context. In addition, the study points out some critical issues. In particular, the LCA analysis did not consider the technical and economical aspects. Thus, starting from the current scenario, three main issues will be investigated in future research. The first issue concerns the development of a life cycle costing analysis (LCC) to determine the most cost-effective option among the four alternatives. The second issue is concerned with the analysis of 
the environmental and economic implications as a function of different distances, which affect the impacts due to transport. Based on these sensitivity analyses, it will be possible to choose the available resources that generate the lowest environmental and adverse economic impacts. The third line of research will be concerned with the investigation of the use of innovative composite materials [64-67].

A last recommendation is for LCA analysists to perform a similar study. Since inventory analysis could vary from one area to another, it is desirable to improve the precision of the LCAdata.

Author Contributions: The authors contributed equally to this manuscript.

Acknowledgments: Ilenia Farina gratefully acknowledges the financial support from the Department of Engineering of the University of Naples Parthenope.

Conflicts of Interest: The authors declare no conflict of interest.

\section{References}

1. Ingrao, C.; Scrucca, F.; Tricase, C.; Asdrubali, F. A comparative Life Cycle Assessment of external wall-compositions for cleaner construction solutions in buildings. J. Clean. Prod. 2016, 124, 283-298. [CrossRef]

2. Rodriguez, G.; Medina, C.; Algre, F.J.; Asensio, E.; Sanchez de Rojas, M.I. Assessment of construction and demolition waste plant management in Spain: In pursuit of sustainability and eco-efficiency. J. Clean. Prod. 2015, 90, 16-24. [CrossRef]

3. Rosse Caldas, L.; Leoni Martins Nascimento, M.; Lima Pinheiro, D.G.; Sposto, R. Literature review of life cycle assessment applied to green concretes. In Proceedings of the 6th Amazon \& Pacific Green Materials Congress and Sustainable Construction Materials Lat-Rilem Conference, Cali, Colombia, 27-29 April 2016.

4. Surahman, U.; Kubota, T.; Higashi, O. Life cycle assessment of energy and $\mathrm{CO}_{2}$ emissions for residential buildings in Jakarta and Bandung, Indonesia. Buildings 2015, 5, 1131-1155. [CrossRef]

5. Limbachiya, M.; Meddah, M.S.; Ouchagour, Y. Use of recycled concrete aggregate in fly-ash concrete. Constr. Build. Mater. 2012, 27, 439-449. [CrossRef]

6. Colomer Mendoza, F.J.; Altabella, J.E.; Gallardo Izquierdo, A. Application of inert wastes in the construction, operation and closure of landfills: Calculation tool. Waste Manag. 2017, 59, 276-285. [CrossRef] [PubMed]

7. Kisku, N.; Joshi, H.; Ansari, M.; Panda, S.K.; Nayak, S.; Dutta, S.C. A critical review and assessment for usage of recycled aggregate as sustainable construction material. Constr. Build. Mater. 2017, 131, 721-740. [CrossRef]

8. Vandenbroucke, M.; Galle, W.; De Temmerman, N.; Debacker, W.; Paduart, A. Using life cycle assessment to inform decision-making for sustainable buildings. Buildings 2015, 5, 536-559. [CrossRef]

9. Oikonomou, N.D. Recycled concrete aggregates. Cem. Concr. Compos. 2005, 27, 315-318. [CrossRef]

10. Colangelo, F.; Messina, F.; Palma, L.D.; Cioffi, R. Recycling of non-metallic automotive shredder residues and coal fly-ash in cold-bonded aggregates for sustainable concrete. Compos. B Eng. 2017, 116, 46-52. [CrossRef]

11. Manzi, S.; Mazzotti, C.; Bignozzi, M.C. Self-compacting concrete with recycled concrete aggregate: Study of the long-term properties. Constr. Build. Mater. 2017, 157, 582-590. [CrossRef]

12. Saccani, A.; Bignozzi, M.C.; Barbieri, L.; Lancellotti, I.; Bursi, E. Effect of the chemical composition of different types of recycled glass used as aggregates on the ASR performance of cement mortars. Constr. Build. Mater. 2017, 154, 804-809. [CrossRef]

13. Seara-Paz, S.; Corinaldesi, V.; González-Fonteboa, B.; Martínez-Abella, F. Influence of recycled coarse aggregates characteristics on mechanical properties of structural concrete. Eur. J. Environ. Civ. Eng. 2016, 20, s123-s139. [CrossRef]

14. Ayati, B.; Ferrándiz-Mas, V.; Newport, D.; Cheeseman, C. Use of clay in the manufacture of lightweight aggregate. Constr. Build. Mater. 2018, 162, 124-131. [CrossRef]

15. Tam, V.W. Comparing the implementation of concrete recycling in the Australian and Japanese construction industries. J. Clean. Prod. 2009, 17, 688-702. [CrossRef]

16. Messina, F.; Ferone, C.; Colangelo, F.; Roviello, G.; Cioffi, R. Alkali activated waste fly ash as sustainable composite: Influence of curing and pozzolanic admixtures on the early-age physico-mechanical properties and residual strength after exposure at elevated temperature. Compos. B Eng. 2018, 132, 161-169. [CrossRef] 
17. Dembovska, L.; Bajare, D.; Ducman, V.; Korat, L.; Bumanis, G. The use of different by-products in the production of lightweight alkali activated building materials. Constr. Build. Mater. 2017, 135, 315-322. [CrossRef]

18. Colangelo, F.; Russo, P.; Cimino, F.; Cioffi, R.; Farina, I.; Fraternali, F.; Feo, L. Epoxy/glass fibres composites for civil applications: Comparison between thermal and microwave crosslinking routes. Compos. B Eng. 2017, 126, 100-107. [CrossRef]

19. Spadea, S.; Farina, I.; Berardi, V.P.; Dentale, F.; Fraternali, F. Energy dissipation capacity of concretes reinforced with recycled PET fibers. Ing. Sismica 2014, 31, 61-70.

20. Meyer, C. The greening of the concrete industry. Cem. Concr. Compos. 2009, 31, 601-605. [CrossRef]

21. Barati, M.; Esfahani, S.; Utigard, T. Energy recovery from high temperature slags. Energy 2011, 36, 5440-5449. [CrossRef]

22. Wang, Z.; Ni, W.; Jia, Y.; Zhu, L.; Huang, X. Crystallization behaviour of glass ceramics prepared from the mixture of nickel slag, blast furnace slag and quartz sand. J. Non-Cryst. Solids 2010, 356, 1554-1558. [CrossRef]

23. Andini, S.; Montagnaro, F.; Santoro, L.; Accardo, G.; Cioffi, R.; Colangelo, F. Mechanochemical processing of blast furnace slag for its reuse as adsorbent. Chem. Eng. Trans. 2013, 32, 2299-2304.

24. Andini, S.; Cioffi, R.; Colangelo, F.; Montagnaro, F.; Santoro, L. Effect of mechanochemical processing on adsorptive properties of blast furnace slag. J. Environ. Eng. 2013, 139, 1446-1453. [CrossRef]

25. Nilsson, M.; Eckerberg, K. Environmental Policy Integration in Practise: Shaping Institutions for Learning; Earthscan: London, UK, 2007.

26. Cuenca-Moyano, G.M.; Zanni, S.; Bonoli, A.; Valverde-Palacios, I. Development of the life cycle inventory of masonry mortar made of natural and recycled aggregates. J. Clean. Prod. 2017, 140, 1272-1286. [CrossRef]

27. Curran, M.A. Life Cycle Assessment; John Wiley \& Sons, Inc.: Hoboken, NJ, USA, 2008.

28. Xiao, D.; Wang, H.; Zhu, J.; Peng, S. Sequent and accumulative life cycle assessment of materials and products. Mater. Des. 2001, 22, 147-149. [CrossRef]

29. Jincheng, X.; Weichang, H.; Xinli, K.; Tianmin, W. Research and development of the object-oriented life cycle assessment database. Mater. Des. 2001, 22, 101-105. [CrossRef]

30. Finkbeiner, M.; Inaba, A.; Tan, R.; Christiansen, K.; Klüppel, H.J. The new international standards for life cycle assessment: ISO 14040 and ISO 14044. Int. J. Life Cycle Assess. 2006, 11, 80-85. [CrossRef]

31. Finnveden, G.; Hauschild, M.Z.; Ekvall, T.; Guinée, J.; Heijungs, R.; Hellweg, S.; Suh, S. Recent developments in life cycle assessment. J. Environ. Manag. 2009, 91, 1-21. [CrossRef] [PubMed]

32. De Souza, D.M.; Lafontaine, M.; Charron-Doucet, F.; Chappert, B.; Kicak, K.; Duarte, F.; Lima, L. Comparative life cycle assessment of ceramic brick, concrete brick and cast-in-place reinforced concrete exterior walls. J. Clean. Prod. 2016, 137, 70-82.

33. Rodrigues Vieira, D.; Calmon, J.L.; Zanellato Coelho, F. Life cycle assessment (LCA) applied to the manufacturing of common and ecological concrete: A review. Constr. Build. Mater. 2016, 124, 656-666. [CrossRef]

34. Colangelo, F.; Cioffi, R. Mechanical properties and durability of mortar containing fine fraction of demolition wastes produced by selective demolition in South Italy. Compos. B Eng. 2017, 115, 43-50. [CrossRef]

35. Colangelo, F.; Petrillo, A.; Cioffi, R.; Borrelli, C.; Forcina, A. Life cycle assessment of recycled concretes: A case study in southern Italy. Sci. Total Environ. 2017, 615, 1506-1517. [CrossRef] [PubMed]

36. Kleijer, A.L.; Lasvaux, S.; Citherlet, S.; Viviani, M. Product-specific life cycle assessment of ready mix concrete: Comparison between a recycled and an ordinary concrete. Resour. Conserv. Recycl. 2017, 122, 210-218. [CrossRef]

37. Turk, J.; Cotič, Z.; Mladenovič, A.; Šajna, A. Environmental evaluation of green concretes versus conventional concrete by means of LCA. Waste Manag. 2015, 45, 194-205. [CrossRef] [PubMed]

38. Estanqueiro, B.; Silvestre, J.D.; de Brito, J.; Pinheiro, M.D. Environmental life cycle assessment of coarse natural and recycled aggregates for concrete. Eur. J. Environ. Civ. Eng. 2016, 22, 429-449. [CrossRef]

39. Naik, T.R. Sustainability of concrete construction. Pract. Period. Struct. Des. Constr. 2008, 13, 98-103. [CrossRef]

40. Bovea, M.D.; Powell, J.C. Developments in life cycle assessment applied to evaluate the environmental performance of construction and demolition wastes. Waste Manag. 2016, 50, 151-172. [CrossRef] [PubMed]

41. Fraj, A.B.; Idir, R. Concrete based on recycled aggregates-Recycling and environmental analysis: A case study of paris' region. Constr. Build. Mater. 2017, 157, 952-964. [CrossRef] 
42. Braga, A.M.; Silvestre, J.D.; de Brito, J. Compared environmental and economic impact from cradle to gate of concrete with natural and recycled coarse aggregates. J. Clean. Prod. 2017, 162, 529-543. [CrossRef]

43. Yazdanbakhsh, A.; Bank, L.C.; Baez, T.; Wernick, I. Comparative LCA of concrete with natural and recycled coarse aggregate in the New York City area. Int. J. Life Cycle Assess. 2017, 1-11. [CrossRef]

44. Marinković, S.; Dragaš, J.; Ignjatović, I.; Tošić, N. Environmental assessment of green concretes for structural use. J. Clean. Prod. 2017, 154, 633-649. [CrossRef]

45. Anastaziou, E.K.; Liapis, A.; Papayianni, I. Comparative life cycle assessmentof concrete road pavements using industrial by-products as alternativematerials. Resour. Conserv. Recycl. 2015, 101, 1-8. [CrossRef]

46. Colangelo, F.; Cioffi, R.; Liguori, B.; Iucolano, F. Recycled polyolefins waste as aggregates for lightweight concrete. Compos. B Eng. 2016, 116, 234-241. [CrossRef]

47. Knoeri, C.; Sanye-Mengual, E.; Althaus, H. Comparative LCA of recycled and conventional concrete for structural applications. Int. J. Life Cycle Assess. 2013, 18, 909-918. [CrossRef]

48. European Commission. Service Contract on Management of Construction and Demolition Waste; SR1, Final Report; European Commission: Paris, France, 2011; p. 240.

49. Blengini, G.A.; Garbarino, E. Resources and waste management in Turin (Italy): The role of recycled aggregates in the sustainable supply mix. J. Clean. Prod. 2010, 18, 1021-1030. [CrossRef]

50. Rosado, L.P.; Vitale, P.; Penteado, C.S.G.; Arena, U. Life cycle assessment of natural and mixed recycled aggregate production in Brazil. J. Clean. Prod. 2017, 151, 634-642. [CrossRef]

51. Colangelo, F.; Messina, F.; Cioffi, R. Recycling of MSWI fly ash by means of cementitious double step cold bonding pelletization: Technological assessment for the production of lightweight artificial aggregates. J. Hazard. Mater. 2015, 299, 181-191. [CrossRef] [PubMed]

52. He, P.J.; Zhang, H.; Zhang, C.G.; Lee, D.J. Characteristics of air pollution control residues of MSW incineration plant in Shanghai. J. Hazard. Mater. 2004, 116, 229-237. [CrossRef] [PubMed]

53. Colangelo, F.; Cioffi, R. Use of cement kiln dust, blast furnace slag and marble sludge in the manufacture of sustainable artificial aggregates by means of cold bonding palletization. Materials 2013, 6, 3139-3159. [CrossRef] [PubMed]

54. Careddu, N.; Marras, G.; Siotto, G.; Orrù, G. Recovery and reuse of marble powder contained in marble slurry waste. In Proceedings of the Symposium Papers of Evaluation of Marble Wastes and Decreasing Environmental Effects, Diyarbakir, Turkey, 16-17 October 2009; pp. 62-69.

55. Ozturk, Z.; Gultekin, E. Preparation of ceramic wall tiling derived from blast furnace slag. Ceram. Int. 2015, 41, 12020-12026. [CrossRef]

56. International Organization for Standardization. Environmental Management_Life Cycle Assessment-Principles and Framework; ISO 14040: 2006; ISO: Geneva, Switzerland, 2006.

57. Mellino, S.; Petrillo, A.; Cigolotti, V.; Autorino, C.; Jannelli, E.; Ulgiati, S. A Life Cycle Assessment of lithium battery and hydrogen-FC powered electric bicycles: Searching for cleaner solutions to urban mobility. Int. J. Hydrog. Energy 2017, 42, 1830-1840. [CrossRef]

58. Marinkovic, S.; Radonjanin, V.; Malesev, M.; Ignjatovic, I. Comparative environmental assessment of natural and recycled aggregate concrete. Waste Manag. 2010, 30, 2255-2264. [CrossRef] [PubMed]

59. Khasreen, M.M.; Banfill, P.F.; Menzies, G.F. Life-cycle assessment and the environmental impact of buildings: A review. Sustainability 2009, 1, 674-701. [CrossRef]

60. Junnila, S.; Horvath, A.; Guggemos, A.A. Life-cycle assessment of office buildings in Europe and the United States. J. Infrastruct. Syst. 2006, 12, 10-17. [CrossRef]

61. Schneider, L.; Berger, M.; Finkbeiner, M. The anthropogenic stock extended abiotic depletion potential (AADP) as a new parameterisation to model the depletion of abiotic resources. Int. J. Life Cycle Assess. 2011, 16, 929-936. [CrossRef]

62. Borghi, G.; Pantini, S.; Rigamenti, L. Life cycle assessment of non-hazardous Construction and Demolition Waste (CDW) management in Lombardy Region (Italy). J. Clean. Prod. 2018, 184, 815-825. [CrossRef]

63. PRé-Consultants. A Damage Oriented Method for Life Cycle Impact Assessment; Methodology Report and Manual for Designers. The Eco-indicator 99 Technical Report; PRé-Consultants: Amersfoort, The Netherlands, 2000.

64. Farina, I.; Fabbrocino, F.; Colangelo, F.; Feo, L.; Fraternali, F. Surface roughness effects on the reinforcement of cement mortars through 3D printed metallic fibers. Compos. B Eng. 2016, 99, 305-311. [CrossRef] 
65. Singh, R.; Dureja, J.S.; Farina, I.; Fabbrocino, F. Investigations for dimensional accuracy of Al alloy/Al-MMC developed by combining stir casting and ABS replica based investment casting. Compos. B Eng. 2017, 115, 203-208. [CrossRef]

66. Farina, I.; Modano, M.; Zuccaro, G.; Goodall, R.; Colangelo, F. Improving flexural strength and toughness of geopolymer mortars through additively manufactured metallic rebars. Compos. B Eng. 2018. [CrossRef]

67. Fabbrocino, F.; Farina, I.; Amendola, A.; Feo, L.; Fraternali, F. Optimal design and additive manufacturing of novel reinforcing elements for composite materials. In Proceedings of the 7th European Congress on Computational Methods in Applied Sciences and Engineering, Crete, Greece, 5-10 June 2016; pp. 5-10. 